\title{
FLYPAPER EFFECT PADA DANA ALOKASI UMUM (DAU) DAN PENDAPATAN ASLI DAERAH (PAD) SERTA PENGARUHNYA TERHADAP BELANJA DAERAH KABUPATEN/KOTA DI SULAWESI TENGAH
}

\author{
Wiwin anggriani salawali ${ }^{1}$, Paulus Kindangen ${ }^{2}$, Agnes L.ch. P. Lapian ${ }^{3}$ \\ Fakultas Ekonomi dan Bisnis, Magister Ilmu Ekonomi \\ Universitas Sam Ratulangi, Manado
}

\begin{abstract}
ABSTRAK
Tujuan dilakukannya penelitian ini adalah untuk mengetahui apakah DAU dan PAD berpengaruh secara signifikan terhadap belanja daerah baik secara parsial dan simultan dan juga untuk mengetahui apakah telah terjadi flypaper effect pada Kabupaten/Kota di Sulawesi Tengah pada tahun 2007 sampai dengan 2012. Objek dari penelitian ini berfokus pada 10 Kabupaten/Kota yang ada di Sulawesi Tengah. Metode analisis yang digunakan dalam penelitian ini adalah model data panel dengan GLS (Generalized Least Squares). Hasil dari penelitian ini menyatakan bahwa secara parsial DAU dan PAD berpengaruh secara signifikan terhadap belanja daerah kabupaten/kota di Provinsi Sulawesi Tengah tersebut pada tahun 2007-2012 karena masing-masing nilai $t$ statistik lebih besar dari t tabel $\alpha=1 \%$ yaitu DAU sebesar 15,293 > 2,704 dan PAD sebesar 3,861>2,704. Secara simultan DAU dan PAD juga berpengaruh secara signifikan terhadap belanja daerah karena nilai $F$ statistik lebih besar dari nilai $F$ tabel $\alpha=1 \%$ yaitu sebesar 165,716 > 99,50. Dalam penelitian juga didapat hasil bahwa terjadi flypaper effect dimana sumber penerimaan terbesar dari DAU yang mempengaruhi besaran belanja di tahun berikunya.
\end{abstract}

Kata kunci : DAU, PAD, Belanja Daerah, Flypaper Effect.

ABSTRACT

The purpose of this study was to determine whether the DAU and PAD significantly influence the local government expenditures both partially and simultaneously and also to know whether there has been a flypaper effect on the districts / cities in Central Sulawesi in 2007 to 2012. The object of this study focuses on 10 districts / cities in Central Sulawesi province. The analytical method used in this study is panel data model with GLS (Generalized Least Squares). The results of this study stated that partially DAU and PAD significantly government spending district / town in Central Sulawesi province in the year 2007-2012 for each value of t statistic is greater than table $\alpha=1 \%$ which amounted to 15.293 DAU > 2.704 and revenue of $3.861>2.704$. Simultaneously DAU and PAD also significantly affect regional spending because the value $F$ statistic is greater than the value of $F$ table $\alpha=1 \%$ in the amount of 165.716 $>99.50$. In the study also obtained results that occur flypaper where the largest revenue source of DAU which affect the amount of spending in the next year.

Keywords : General Allocation Funds, Local Own Source Revenue, Regional Expenditure, Flypaper Effect

\section{Latar Belakang Masalah}

\section{PENDAHULUAN}

Transfer antarpemerintah sebagai bentuk dari kebijakan pelaksanaan otonomi dalam mengatasi kesenjangan fiskal dan merupakan salah satu sumber penerimaan penting pemerintah daerah. Menurut Simanjuntak tujuan utama dari transfer adalah untuk mengurangi kesenjangan fiskal antarpemerintah dan menjamin tercapainya standar pelayanan publik minimum diseluruh daerah (dalam Maimunah, 2006). Meskipun demikian pemberian transfer juga mengakibatkan ketidakefektifan pembiayaan pengeluaran daerah. Fenomena tersebut dikenal dengan flypaper effect.

Setiap daerah di Indonesia memiliki perbedaan potensi, kebutuhan daerah dan sumber daya serta beban fungsi antartingkat pemerintahan (Al Khoiri, 2015). Keadaan ini menimbulkan kemampuan keuangan (revenue capacity) yang berbeda-beda antardaerah. Untuk menyeimbangkan ketimpangan sumber pendanaan antara pusat dan daerah, maka ditetapkan transfer dana perimbangan salah satunya yaitu DAU. Ada dua faktor utama yang menentukan besarnya transfer DAU dari pemerintah pusat ke pemerintah daerah. Faktor pertama adalah kebutuhan daerah (needs), faktor kedua adalah kemampuan finansial daerah yang adalah kemampuan dasar dalam membiayai belanja daerah yang berasal dari PAD dan DAU (Kurnia, 2013). 
Menurut LPEM-UI (2002) untuk melihat kesiapan pemerintah daerah dalam menghadapi otonomi daerah khususnya dibidang keuangan, diukur dari seberapa jauh kemampuan pembiayaan urusan bila didanai sepenuhnya oleh PAD. Salah satu fenomena yang mencolok dari otonomi daerah di Indonesia adalah ketergantungan pemerintah daerah yang tinggi terhadap pemerintah pusat. Ketergantungan ini terlihat jelas dari aspek keuangan. Alokasi transfer DAU yang diberikan pemerintah pusat kepada pemerintah daerah lebih tinggi dan kurang memperhatikan kemampuan daerah dalam mengoptimalkan sumber-sumber pendanaannya. Akibatnya pemerintah daerah akan selalu menuntut transfer yang besar dari pemerintah pusat, bukannya memaksimalkan kapasitas fiskal daerah (potensi fiskal). Ketergantungan ini akan menimbulkan rendahnya peran daerah itu sendiri dalam mendanai belanja daerah serta semakin dominanya peran transfer dari pusat dalam hal ini adalah DAU, maka disebut flypaper effect (Purbarini, 2015). Naganathan dan Sivagnanam (1999) menyatakan bahwa alokasi transfer di negara-negara sedang berkembang pada umumnya lebih banyak didasarkan pada aspek belanja tetapi kurang memperhatikan kemampuan pengumpulan pajak lokal. Akibatnya, menurut Oates dari tahun ke tahun pemerintah daerah selalu menuntut transfer yang lebih besar lagi dari pusat, bukannya mengeksplorasi basis pajak lokal secara lebih optimal (dalam Purnomo, 2010). Keadaan tersebut juga ditemui pada kasus pemerintah daerah kabupaten/kota di Indonesia. Data menunjukkan proporsi PAD hanya mampu membiayai belanja pemerintah daerah paling tinggi sebesar 20 persen (Purbarini, 2015). Permasalahan yang terjadi saat ini, pemerintah daerah terlalu menggantungkan alokasi DAU untuk membiayai belanja modal dan pembangunan tanpa mengoptimalkan potensi yang dimiliki daerah. Disaat alokasi DAU yang diperoleh besar, maka pemerintah daerah akan berusaha agar pada periode berikutnya DAU diperoleh tetap porsi nominalnya. Menurut Afrizawati (2012) proporsi DAU terhadap penerimaan daerah masih yang tertinggi dibandingkan dengan penerimaan daerah yang lain, termasuk PAD. Kuncoro (2007) juga menyebutkan bahwa PAD hanya mampu membiayai belanja pemerintah daerah paling besar $20 \%$. Respon disini merupakan suatu tanggapan langsung dari pemerintah daerah dalam menyikapi transfer dana dalam bentuk dana perimbangan khususnya DAU yang diwujudkan pada anggaran belanja daerah. Ketika respon (belanja) daerah lebih besar terhadap transfer, maka disebut dengan flypaper effect (Maimunah, 2006). Secara keseluruhan perkembangan keuangan daerah menunjukan hubungan yang tidak simetris, dimana perubahan pertumbuhan antara PAD dengan belanja daerah jauh lebih rendah, dibandingkan perubahan pertumbuhan DAU dengan belanja daerah. Hal ini terlihat indikasi kuat perilaku belanja daerah sangat dipengaruhi sumber penerimaan berupa dana transfer yaitu DAU sehingga akan melemahkan kemampuan daerah dalam membiayai kebutuhan sendiri. Sulawesi Tengah merupakan salah satu provinsi yang daerahnya mengalami proses pemekaran, dengan tiga belas kabupaten/kota yang terdiri dari sepuluh kabupaten/kota induk pemekaran dan tiga kabupaten/kota hasil pemekaran secara tidak langsung berimbas pada porsi penerimaan dana transfer (grants) dari pusat. Dengan adanya hal tersebut diharapkan pemerintah daerah dapat lebih mampu dalam berinovasi serta mengeksplorasi sumber-sumber alam yang terkandung di wilayah masing-masing. Sehingga lambat laun ketergantungan pada pusat dapat dihilangkan, seiring dengan adanya penambahan PAD. Realisasi pendapatan daerah di kabupaten/kota di Sulawesi Tengah jumlah dan kenaikan kontribusi PAD memiliki peranan dalam rencana peningkatan kemampuan dari segi keuangan agar tidak harus selalu bergantung pada pemerintah pusat. PAD merupakan representasi pendapatan yang dihasilkan oleh daerah tersebut.

Dengan karakteristik data PAD, DAU dan belanja daerah yang berfluktuasi seperti diatas maka kemungkinan besar terjadi flypaper effect pada daerah kabupaten/kota, dalam hal ini dilihat dari besarnya nilai DAU daripada nilai PAD . Oleh karena itu maka penulis ingin meneliti tentang " Flypaper Effect Pada Dana Alokasi Umum (DAU) dan Pendapatan Asli Daerah (PAD) Serta Pengaruhnya Terhadap Belanja Daerah Kabupaten/kota di Sulawesi Tengah"

\section{Rumusan Masalah}

Berdasarkan pada uraian latar belakang, maka rumusan masalah dalam penelitian ini adalah:

1. Bagaimana pengaruh DAU dan PAD terhadap belanja daerah?

2. Mengapa flypaper effect menyebabkan peningkatan terhadap jumlah belanja daerah?

\section{Tujuan Penelitian}

Tujuan penelitian ini adalah : 
1. Untuk memberikan bukti empiris dari DAU dan PAD terhadap belanja daerah kabupaten/kota Provinsi Sulawesi Tengah.

2. Membuktikan flypaper effect menyebabkan peningkatan jumlah belanja daerah ditahun berikutnya

\section{Manfaat Penelitian}

Manfaat penelitian dilihat baik dari segi teori maupun terapan antara lain :

1. Sebagai masukan dan tambahan referensi bagi pihak-pihak yang ingin mengambil penelitian dan studi pustaka tentang keuangan daerah

2. Menjadi bahan evaluasi tentang kebijakan keuangan daerah bagi pemerintah daerah kabupaten/kota di Provinsi Sulawesi Tengah khususnya, dan Indonesia pada umumnya

\section{Landasan Teori \\ Otonomi Daerah}

Otonomi berasal dari kata Yunani autos dan nomos. Kata pertama berarti sendiri dan kata kedua berarti pemerintah. Otonomi bermakna memerintah sendiri, dalam wacana administrasi publik daerah sering disebut sebagai local self government. Melalui UU No. 23 tahun 2014 tentang pemerintahan daerah, maka otonomi daerah yang seluas-luasnya mulai ditempatkan pada daerah kabupaten/kota serta diserahkan juga kewenangan yang lebih besar pada pemerintah kabupaten/kota.

Menurut Saragih (2003) otonomi sendiri berarti adanya kebebasan menjalankan atau melaksanakan sesuatu oleh suatu unit politik atau bagian wilayah dalam kaitannya dengan masyarakat politik atau negara. Konsep otonomi daerah adalah bahwa kewenangan untuk menjalankan fungsi atau mengurus daerah sendiri tidak datang begitu saja tetapi merupakan keputusan politik yang ditempuh guna meningkatkan efektivitas penyelenggaraan pemerintahan, pelayanan publik dan pembangunan (dalam Kurnia, 2013). Tujuan pemberian otonomi daerah adalah untuk memungkinkan daerah yang bersangkutan mengatur dan mengurus rumah tangga sendiri dalam rangka meningkatkan daya guna dan hasil guna penyelenggaraan pemerintahan bagi pelayanan masyarakat dan pelaksanaan pembangunan. Sebagai upaya untuk mencapai tujuan itu, maka kepada daerah diberikan wewenang untuk melaksanakan urusan pemerintahan.

\section{Desentralisasi Fiskal}

Desentralisasi fiskal merupakan komponen utama dari desentralisasi yang artinya desentralisasi tidak dapat dilepaskan dari isu kapasitas keuangan daerah, dimana kemandirian keuangan daerah berdasarkan kemampuan menggali dan mengelola keuangannya. Menurut Saragih (2003) desentralisasi fiskal secara singkat dapat diartikan sebagai suatu proses distribusi anggaran dari tingkat pemerintahan yang lebih tinggi kepada pemerintahan yang lebih rendah, untuk mendukung fungsi atau tugas pemerintahan dan pelayan publik sesuai dengan banyaknya kewenangan bidang pemerintahan yang dilimpahkan (dalam Kurnia, 2013). Menurut UU No. 23 Tahun 2014 tentang pemerintahan daerah pada bagian Perimbangan Keuangan Antara Pusat dan Daerah disebutkan bahwa desentralisasi adalah penyerahan wewenang pemerintahan oleh pemerintah kepada daerah otonom untuk mengatur dan mengurus urusan pemerintahan dalam sistem Negara Kesatuan Republik Indonesia. Definisi desentralisasi menurut Yustika (2008) menyangkut berbagai bentuk dan dimensi yang beragam, terutama berkaitan dengan aspek fiskal, politik, administrasi dan sistem pemerintahan serta pembangunan secara sosial dan ekonomi.

Anggaran daerah atau Anggaran Pendapatan dan Belanja Daerah (APBD) sebagai salah satu bentuk dari desentralisasi fiskal, merupakan instrumen kebijakan fiskal yang utama bagi pemerintah daerah dan juga menunjukan kapasitas dan kemampuan daerah. Menurut Oates (1999) ada dua bentuk instrumen fiskal yang penting pada sistem federal yaitu pajak, dan hibah antarpemerintah (intergovermental grants) dan bagi hasil pendapatan (revenue sharing). Menurut Usui dan Alisjahbana, kunci utama dari desentralisasi fiskal adalah pembuatan menjadi lebih dekat dengan masyarakat sehingga distribusi pelayanan publik menjadi lebih muda dalam memenuhi kebutuhan masyarakat lokal (dalam Handayani, 2009).

\section{Teori Penerimaan Pendapatan Daerah}

Adapun hubungan pendapatan daerah dengan beragam variabel fisik dan sosial ekonomi adalah untuk mengidentifikasikan variabel mana yang mempunyai pengaruh terbanyak terhadap penerimaan pendapatan 
daerah. Meskipun perbedaan tidak berlaku di semua wilayah dengan kekuatan (tingkatan) yang sama, tetapi terdapat aspek-aspek umum yang dapat memberikan beberapa generalisasi penyebab utama perbedaan pendapatan daerah (Mardiasmo, 2002).

1. Faktor Geografis

Apabila suatu wilayah yang sangat luas, distribusi dari sumber daya nasional, sumber energi, sumber daya pertanian, topografi, iklim dan curah hujan tidak akan merata. Apabila faktor-faktor lain sama, maka kondisi geografi yang lebih baik akan menyebabkan suatu wilayah berkembang lebih baik

2. Faktor Historis

Tingkat pembangunan suatu masyarakat juga bergantung pada masa yang lalu untuk menyiapkan masa depan. Bentuk organisasi ekonomi yang hidup di masa lalu menjadi alasan penting yang dihubungkan dengan isu insentif, untuk pekerja dan pengusaha. Sistem feodal memberikan sangat sedikit insentif untuk pekerja keras. Sistem industri dimana pekerja merasa tereksploitasi, bekerja tanpa istirahat, suatu perencanaan dan sistem yang membatasi akan memberi sedikit insentif dan menyebabkan pembangunan terhambat.

\section{Faktor Politik}

Ketidakstabilan politik dapat menjadi penghambat pembangunan yang sangat kuat. Tidak stabilnya suhu politik sangat memengaruhi perkembangan dan pembangunan di suatu wilayah. Instabilitas politik akan menyebabkan orang ragu untuk berusaha atau melakukan investasi sehingga kegiatan ekonomi disuatu wilayah tidak akan berkembang. Selain itu, jika pemerintah stabil tapi lemah, korupsi dan ketidakmampuan untuk mengalahkan sikap mementingkan diri sendiri dan menolak tekanan atau kontrol sosial akan menggagalkan tujuan dari kebijakan pembangunan.

4. Faktor Administrasi (birokrasi)

Faktor administrasi yang efisien atau tidak efisien berpengaruh dalam menambah kesenjangan antarwilayah. Saat ini pemerintah dalam menjalankan fungsinya membutuhkan administrator yang jujur, terdidik, terlatih dan efisien karena birokrasi yang efisien akan berhasil dalam pembangunan regional dan sebaliknya.

5. Faktor Sosial

Banyak faktor sosial yang menjadi penghalang dalam pembangunan. Penduduk di wilayah yang belum berkembang tidak memiliki lembaga dan keinginan (attitude) yang kondusif untuk pembangunan ekonomi. Dilain pihak penduduk dari wilayah yang lebih maju memiliki kelembagaan dan keinginan yang kondusif untuk pembangunan.

6. Faktor Ekonomi

Penyebab secara ekonomis seperti perbedaan dalam faktor produksi, proses kumulatif dari berbagai faktor, siklus kemiskinan yang buruk, kekuatan pasar yang bebas dan pasar tidak sempurna, berlangsung yang menambah perbedaan dalam pembangunan ekonomi.

PAD merupakan salah satu komponen sumber penerimaan daerah sebagaimana diatur dalam pasal 79 UU Nomor 22 Tahun 1999, serta PP Mendagri Nomor 13 Tahun 2006 mengenai pengelolaan keuangan daerah, direvisi menjadi PP Mendagri Nomor 59 Tahun 2007 bahwa sumber pendapatan daerah terdiri dari A. Pendapatan Asli Daerah yaitu : hasil pajak daerah, hasil retribusi daerah, hasil perusahaan milik daerah dan hasil pengelolaan kekayaan daerah yang dipisahkan lain-lain pendapatan asli daerah yang sah, B. Dana Perimbangan, C. Pinjaman Daerah D. Lain-lain pendapatan daerah yang sah.

1. Hasil Pajak Daerah.

Jenis pajak yang dipungut oleh pemerintah propinsi yaitu pajak kendaraan bermotor, bea balik nama kendaraan bermotor, pajak bahan bakar kendaraan bermotor, pajak pengambilan dan pemanfaatan air bawah tanah dan air permukaan. Sedangkan jenis pajak daerah untuk kabupaten terdiri dari pajak hotel, pajak restoran, pajak hiburan, pajak reklame, pajak penerangan jalan, pajak pengambilan bahan galian golongan $\mathrm{C}$.

2. Hasil Retribusi Daerah.

Retribusi Daerah adalah pungutan daerah sebagai pembayaran atas jasa atau pemberian izin tertentu yang khusus disediakan dan atau diberikan oleh pemerintah daerah untuk kepentingan orang pribadi atau 
badan. Ada tiga golongan retribusi daerah yaitu retribusi jasa umum, retribusi jasa usaha, dan retribusi perizinan tertentu.

(a) Retribusi jasa umum. Yaitu retribusi atas jasa yang diberikan emerintah daerah untuk tujuan kepentingan umum serta dapat dinikmati oleh orang pribadi atau badan.

(b) Retribusi Jasa Usaha. Yaitu retribusi atas jasa yang disediakan oleh pemerintah daerah dengan menganut prinsip komersial karena pada dasarnya dapat pula disediakan oleh sektor swasta.

(c) Retribusi perizinan tertentu. Yaitu retribusi atas kegiatan tertentu pemerintah daerah dalam rangka pemberian izin kepada orang pribadi atau badan yang dimaksudkanuntuk pembinaan, pengaturan, pengendalian dan pengawasan atas kegiatan pemanfaatan ruang, penggunaan sumber daya alam, barang, prasarana, sarana/fasilitas tertentu guna melindungi kepentingan umum dan kelestarian lingkungan.

3. Hasil perusahaan milik daerah dan hasil pengelolaan kekayaan daerah lainnya yang dipisahkan. Yang termasuk dalam jenis pendapatan ini yaitu deviden atau bagian laba yang diperoleh oleh Badan Usaha Milik Daerah (BUMD) yang dibagikan bagi pemegang saham, dalam hal ini merupakan pendapatan bagi pemerintah daerah.

4. Lain-lain pendapatan asli daerah yang sah. Yang tergolong dalam jenis pendapatan ini antara lain pendapatan bunga deposito, jasa giro, hasil penjualan surat berharga investasi, pendapatan dari ganti rugi atas kerugian/kehilangan kekayaan daerah, denda, penggantian biaya, dan lain-lain.

\section{Kerangka Pikir}

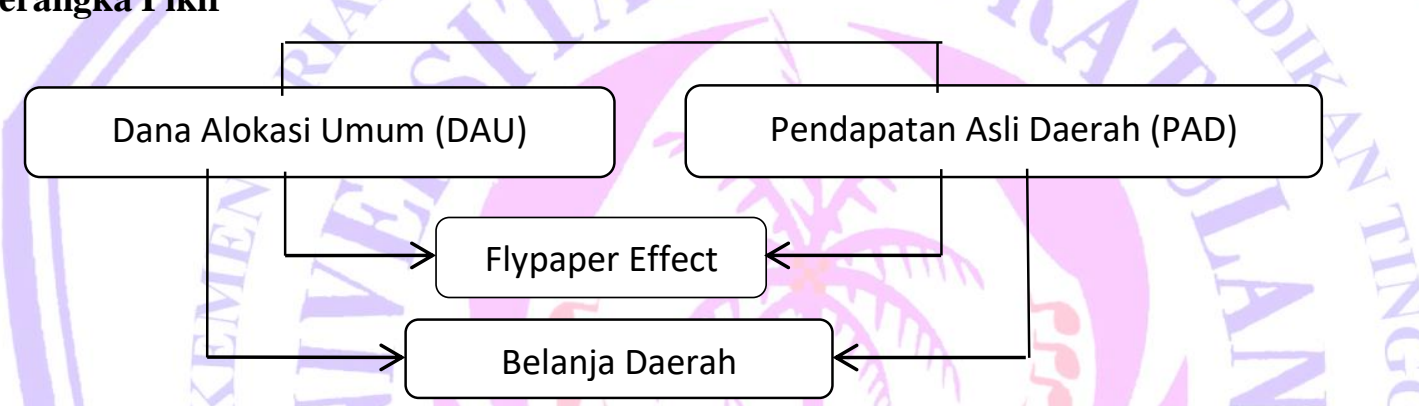

Gambar 1 Kerangka Pikir Flypaper Effect pada DAU dan PAD serta pengaruhnya terhadap Belanja Daerah Kabupaten/Kota Di Sulawesi Tengah

\section{METODE PENELITIAN}

\section{Ruang Lingkup Penelitian}

Penelitian ini membatasi dan memfokuskan pada pengaruh Dana Alokasi Umum (DAU) dan Pendapatan Asli Daerah (PAD) terhadap Belanja Pemerintah Daerah (BD) dan flypaper effect pada peningkatan jumlah belanja daerah di era otonomi dengan data yang digunakan merupakan data tahunan yakni tahun 2007 sampai dengan tahun 2012.

\section{Metode Pengumpulan Data}

Teknik pengumpulan data yang dipergunakan adalah melalui data sekunder dengan jenis data time series dan cross section. Sumber data yang diperlukan dalam penelitian ini berasal dari Badan Pusat Statistik (BPS) Sulawesi Tengah, referensi studi kepustakaan melalui, jurnal, artikel, makalah yang didapat dari perpustakaan dan internet.

\section{Metode Pengambilan Sampel}

Penelitian ini mengambil lokasi kabupaten dan kota di Provinsi Sulawesi Tengah. Objek penelitian ini adalah laporan keuangan pemerintah kabupaten dan kota di Sulawesi Tengah. Populasi yang menjadi bahan penelitian ini adalah laporan keuangan daerah yang tersebar diseluruh kabupaten dan kota di Sulawesi Tengah. Seluruh pemerintah kabupaten dan kota dijadikan sampel penelitian (sampel jenuh), kecuali Kabupaten Sigi, Kabupaten Banggai Laut, dan Kabupaten Morowali Utara dengan periode pengamatan tahun anggaran $2007-2012$. 


\section{Definisi Operasional dan Pengukuran Variabel}

Berdasarkan kajian pustaka dan penelitian terdahulu yang diuraikan pada bab sebelumnya, variabel terikat (dependent variable) dalam penelitian ini adalah Belanja Daerah (BD) sedangkan variabel bebas (independent variable) adalah Dana Alokasi Umum (DAU) dan Pendapatan Asli Daerah (PAD). Definisi operasional dan pengukuran variabel tersebut adalah sebagai berikut.

\section{Belanja Daerah (BD)}

Belanja Daerah adalah semua kewajiban kabupaten/kota di Provinsi Sulawesi Tengah sebagai pengurang nilai kekayaan bersih dalam hal ini belanja daerah yang terdiri dari belanja langsung dan belanja tidak langsung dengan periode tahun anggaran 2007 sampai dengan 2012 dengan satuan rupiah.

\section{Dana Alokasi Umum (DAU)}

DAU adalah dana yang bersumber dari pendapatan APBN yang dialokasikan untuk pemerataan kemampuan keuangan antardaerah untuk membiayai kebutuhan pengeluarannya dalam rangka pelaksanaan desentralisasi. Variabel DAU yang digunakan dalam penelitian ini adalah DAU kabupaten/kota di Provinsi Sulawesi Tengah dalam periode tahun anggaran 2007 sampai dengan 2012 dengan satuan rupiah.

\section{Pendapatan Asli Daerah (PAD)}

Pendapatan Asli Daerah adalah pendapatan yang diperoleh daerah kabupaten/kota di Provinsi Sulawesi Tengah pada periode tahun anggaran 2007 sampai dengan 2012 dengan satuan rupiah yang dipungut berdasarkan peraturan daerah sesuai dengan peraturan perundang-undangan.

\section{Flypaper Effect}

Flypaper effect adalah suatu kondisi yang terjadi saat pemerintah daerah merespon belanja lebih banyak dengan menggunakan dana transfer (grants) yaitu DAU dibandingkan dengan menggunakan kemampuan sendiri yaitu PAD.

\section{Metode Analisis}

Metode analisis yang digunakan adalah analisis kuantitatif dengan menggunakan model ekonometrika dengan bantuan program Eviews 8 dan Microsoft Excel.

\section{Model Data Panel}

Didalam ilmu ekonometrika, ada 3 (tiga) bentuk data yang dikenal yakni time series (lintas waktu), cross section (lintas sektor) dan data panel. Pada data time series permasalahan yang sering muncul adalah tidak terpenuhinya syarat jumlah data minimal (> 30 sampel) saat melalukan proses estimasi. Pada data cross section permasalahan yang sering muncul adalah jumlah unit cross section yang terbatas. Sehingga tujuan proses estimasi untuk mendapatkan informasi perilaku dari model penelitian sulit dilakukan.

Dalam penelitian ini yang termasuk data time series adalah tahun anggaran 2007 sampai dengan tahun anggaran 2012 sedangkan data dari 10 kabupaten/kota di Provinsi Sulawesi Tengah merupakan data cross section. Dalam penelitian ini akan menggunakan statistik regresi linier berganda (multiple regression) untuk data panel. Teknik ini digunakan dengan tujuan untuk menguji hipotesis penelitian yang telah disebutkan pada bab sebelumnya. Sebagai alat analisis akan dilakukan regresi model ekonometrika yang menggunakan teknik estimasi dengan pendekatan data panel.

1. Model Belanja Daerah (BD) digunakan untuk menganalisis pengaruh DAU dan PAD terhadap BD dengan persamaan sebagai berikut.

$\mathrm{BDit}=\mathrm{a}+\beta_{1} \mathrm{DAUi}_{\mathrm{t}}+\beta_{2} \mathrm{PADi}_{\mathrm{t}}+\mathrm{ei}_{\mathrm{t}}$

2. Model Belanja Daerah (BD) digunakan untuk menganalisis pengaruh DAU dan PAD tahun sebelumnya terhadap $\mathrm{BD}$ tahun berjalan dengan persamaan sebagai berikut.

$\mathrm{BDit}=\mathrm{a}+\beta_{1} \mathrm{DAUi}_{\mathrm{t}-1}+\beta_{2} \mathrm{PADi}_{\mathrm{t}-1}+\mathrm{ei}_{\mathrm{t}}$

Dimana :

BDit = Belanja Daerah $(\mathrm{BD})$

DAUi $_{t}=$ Dana Alokasi Umum (DAU) tahun tersebut 
DAUi $_{\mathrm{t}-1}=$ Dana Alokasi Umum (DAU) tahun sebelumnya

PADi $_{\mathrm{t}}=$ Pendapatan Asli Daerah (PAD) tahun tersebut

$\mathrm{PADi}_{\mathrm{t}-1}=$ Pendapatan Asli Daerah $(\mathrm{PAD})$ tahun sebelumnya

a $\quad=$ konstanta

$\beta_{1,} \beta_{2} \quad=$ koefisien regresi

e $\quad=$ error term

\section{Pemilihan Model Estimasi Data Panel}

Teknik analisis data panel dalam penelitian ini dapat dilakukan dengan metode effek tetap (fixed effect) atau metode efek acak (random effect), sedangkan untuk melakukan metode mana yang lebih sesuai dalam penelitian ini digunakan uji Hausman (Hausman test).

\section{Metode effek tetap (fixed effect)}

Metode ini digunakan untuk mengatasi kelemahan analisis data panel dengan menggunakan model OLS (Ordinary Least Square). Penggunaan OLS untuk data panel adalah tidak realistis karena akan menghasilkan intercept maupun slope pada data panel yang tidak berubah baik antara individu (cross section) maupun antar waktu (time series).

\section{Metode effek acak (random effect)}

Metode yang tepat digunakan untuk mengestimasi model random effek adalah Generalized Least Square $(G L S)$. Dalam metode random effect, perbedaan karakteristik individu dan antar waktu diakomodasikan pada error pada model. Mengingat terdapat dua komponen yang mempunyai kontribusi pada pembentukan error (yaitu individu dan waktu), maka pada metode ini perlu diurai menjadi error untuk komponen individu, error untuk kompenen waktu dan error untuk gabungan.

\section{Uji Hausman (Hausman test)}

untuk mengestimasi regresi data panel yang tepat digunakan, yakni dengan menggunakan uji Hausman. Uji Hausman digunakan untuk memilih antara model fixed effect atau model random effect. Pengujian ini dilakukan dengan hipotesa sebagai berikut.

$\mathrm{H} 0$ : random effect model

$\mathrm{H} 1$ : fixed effect model

- apabila chi-square statistik > chi-square tabel, maka H0 ditolak dan model fixed effect lebih tepat untuk digunakan.

- apabila chi-square statistik < chi-square tabel, maka H1 ditolak dan model random effect lebih tepat untuk digunakan (Widardjono, 2013).

\section{Analisis Flaypaper Effect}

Untuk melihat apakah terjadi flypaper effect atau tidak dapat dilihat dari perbandingan antara koefisien DAU dan koefisien PAD, atau dapat difungsikan jika

b1 > b2 berarti $\frac{\mathrm{b} 1}{\mathrm{~b} 2}>1$ maka terjadi flypaper effect (Tresch, 2002:924)

menurut Pentury (2011), untuk mengatahui apakah terjadi flypaper effect atau tidak di suatu daerah, maka dapat dilakukan dengan dua (2) cara yaitu

a. Dengan melihat pengaruh dari PAD. Jika PAD tidak memiliki pengaruh yang signifikan terhadap belanja daerah maka dapat dikatakan bahwa telah terjadi flypaper effect.

b. Melihat nilai koefisien dari variabel independent, yaitu DAU dan PAD. Jika nilai koefisien yang dimiliki oleh PAD lebih besar dari nilai koefisien yang dimiliki oleh DAU maka dapat dikatakan tidak terjadi flypaper effect. Sedangkan sebaliknya jika nilai koefisien yang dimiliki oleh salah satu yang berasal dari transfer daerah yaitu DAU lebih besar daripada nilai koefisien dari PAD maka dapat dikatakan telah terjadi flypaper effect. 


\section{Uji Asumsi Regresi Linier Berganda}

Didalam persamaan model regresi linier berganda, dikenal beberapa uji asumsi dasar untuk menilai suatu model dengan maksud untuk mengetahui apakah persamaan model regresi yang ditentukan tersebut merupakan model yang dapat menghasilkan estimasi yang tidak bias. Uji asumsi tersebut dapat diuraikan sebagai berikut.

\section{Uji Multikolinearitas}

Uji Multikolinieritas dilakukan untuk mengetahui ada tidaknya hubungan yang signifikan diantara variabel bebas. Deteksi adanya multikolinieritas dilakukan dengan regresi suatu variabel bebas terhadap variabel bebas lain dalam model. Untuk menguji ada tidaknya multikolinieritas. Untuk menguji ada tidaknya multikolinieritas dapat dilihat dari nilai R-Square, F-hitung serta standar error.

H0 : jika nilai R-square < nilai R-square model utama hal ini menunjukan bahwa tidak ada masalah Multikolinieritas.

Hi : Jika nilai R-square > nilai R-square model utama hal ini menunjukan bahwa ada masalah multikolineritas.

\section{Uji Heterokedastisitas}

Salah satu cara untuk mendeteksi ada tidaknya masalah heterokedastisitas dilakukan dengan menggunakan pengujian White Heterokedasticity Test.

H0 : jika nilai obs chi-square statistik < nilai chi-square tabel dengan derajat kepercayaan tertentu $(\alpha)$ menunjukan tidak adanya heterokedastisitas

H1 : Jika nilai obs chi-square statistik > nilai chi-square tabel dengan derajat kepercayaan tertentu $(\alpha)$ maka ada heteroskedastisitas.

\section{Uji Autokorelasi}

Uji Autokorelasi dimaksudkan untuk mengetahui apakah terdapat korelasi residual satu observasi dengan observasi lainnya.

Pengujian Aotukorelasi dilakukan salah satunya dengan Breusch-GodfreySerial Correlation LM Test .

H0: Jika nilai obs chi-square statistik < nilai chi square tabel dengan derajat kepercayaan tertentu $(\alpha)$ maka tidak terjadi Autokorelasi.

H1 : Jika nilai obs chi-square statistik > nilai chi square tabel dengan derajat kepercayaan tertentu $(\alpha)$ maka terjadi Autokorelasi.

\section{Uji Statistik}

Untuk memperoleh model regresi yang terbaik atau BLUE (Best Linier Unbiased Estimator) beberapa kriteria yang harus dipenuhi antara lain dengan melakukan Uji F dan uji t.

\section{Uji Signifikansi Simultan (Uji Statistik F)}

Uji statistik F pada dasarnya menunjukan apakah semua variabel bebas yang dimasukkan dalam model mempeunyai pengaruh secara serentak (simultan) terhadap variabel dependent/terikat dengan menggunakan hipotesis sebagai berikut.

H0 : $\quad$ Tidak ada pengaruh signifikan variabel bebas secara serentak terhadap variabel terikat

H1 : Ada pengaruh signifikan variabel bebas secara serentak terhadap variabel terikat

Cara melakukan uji $\mathrm{F}$ adalah dengan membandingkan nilai statistik $\mathrm{F}$ hasil perhitungan ( $\mathrm{F}$ hitung) dengan nilai $F$ menurut tabel ( $F$ tabel) pada derajat kepercayaan $(\alpha)$ sebesar 1\%. Apabila hasil perhitungan menunjukan :

- F hitung > F tabel, maka H0 ditolak dan H1 diterima

Suatu variabel bebas secara simultan merupakan penjelas yang signifikan terhadap variabel terikat

- F hitung < F tabel, maka H0 diterima dan H1 ditolak

Suatu variabel bebas secara simultan bukan merupakan penjelas yang signifikan terhadap variabel terikat

2. Uji Secara Parsial (Uji Statistik t) 
Uji statistik t pada dasarnya menunjukan seberapa jauh satu pengaruh variabel penjelas/independen secara individual dalam menerangkan variasi-variasi variabel dependen dengan menggunakan hipotesis sebagai berikut.

HO : suatu variabel independen secara individual bukan merupakan penjelas yang signifikan terhadap variabel dependen

H1 : suatu variabel independen secara individual merupakan penjelas yang signifikan terhadap variabel dependen

Cara melakukan uji $\mathrm{t}$ adalah dengan membandingkan nilai statistik $\mathrm{t}$ hasil perhitungan ( $\mathrm{t}$ hitung) dengan nilai $\mathrm{t}$ menurut tabel ( $\mathrm{t}$ tabel) pada derajat kepercayaan $(\alpha)$ sebesar $1 \%$. Apabila hasil perhitungan menunjukan :

- $\mathrm{t}$ hitung > t tabel, maka H0 ditolak dan $\mathrm{H} 1$ diterima

artinya variasi variabel independen dapat menerangkan variabel dependen dan terdapat pengaruh diantara kedua variabel yang diuji, dengan kata lain menerima hipotesis yang menyatakan bahwa suatu variabel independen secara individual mempengaruhi variabel dependen

- t hitung < t tabel, maka H0 diterima dan H1 ditolak

artinya variasi variabel independen tidak dapat menerangkan variabel dependen dan tidak terdapat pengaruh diantara kedua variabel yang diuji, dengan kata lain menerima hipotesis yang menyatakan bahwa suatu variabel independen bukan merupakan penjelas yang signifikan terhadap variabel dependen.

3. Koefisien Determinasi $\left(\mathbf{R}^{2}\right)$

Koefisien Determinasi $\left(\mathrm{R}^{2}\right)$ adalah koefísien nilai statistik yang dapat digunakan untuk mengetahui apakah ada hubungan pengaruh antara dua variabel. Nilai Koefisien Determinasi $\left(R^{2}\right)$ menunjukan persentase variasi nilai variabel terikat yang dapat dijelaskan oleh persamaan regresi yang dihasilkan. Semakin besar nilai $\mathrm{R}^{2}$ berarti semakin tepat suatu garis regresi digunakan sebagai pendekatan. Sebaliknya semakin kecil nilai $\mathrm{R}^{2}$ berarti semakin tidak tepat garis regresi tersebut mewakili data dari hasil observasi.

\section{HASIL DAN PEMBAHASAN}

\section{Analisis Model Regresi Data Panel}

Dalam sub bab ini akan dibahas dan dianalisis secara statistik dan ekonomi berdasarkan model ekonometrika. Analisis dilakukan pada setiap model pengujian data panel sehingga didapat suatu pembahasn yang spesifik terhadap masing-masing model

\section{Pemilihan Estimasi Dalam Model Data Panel}

Langkah awal sebelum melakukan analisis model regresi dengan data panel, terlebih dahulu akan dilakukan uji Hausman untuk memilih diantara metode fixed effect atau metode random effect. Adapun hipotesis yang digunakan dalam uji hausman ini adalah sebagai berikut.

H0 : $\quad$ Metode effect acak (random effect)

H1 : $\quad$ Metode effect tetap (fixed effect)

Statistik uji Hausman mengikuti distribusi statistik chi-square dengan degree of freedom sebanyak $k$ dimana $k$ adalah jumlah variabel bebas. Jika nilai chi-square statistik Hausman lebih besar dari nilai chi-square tabel maka model yang tepat adalah model fixed effect dan jika nilai chi-square statistiknya lebih kecil dari nilai tabel maka model yang tepat adalah model random effect. 
Tabel 1 Hasil Uji signifikansi Fixed Effect atau Random Effect dengan metode Hausman Test

\begin{tabular}{ccccc}
\hline \hline Test Summary & \multicolumn{1}{c}{ Chi-Sq. Statistic } & Chi-Sq. d.f. & Prob. \\
\hline \hline Cross-section random & & $\mathbf{1 . 6 5 7 4 3 8}$ & 2 & 0.4366 \\
\hline \hline $\begin{array}{c}\text { Cross-section random effects test comparisons: } \\
\text { Variable }\end{array}$ & Fixed & Random & Var(Diff.) & Prob. \\
\hline \hline DAU & 1.367518 & 1.288182 & 0.006097 & 0.3096 \\
PAD & 0.134985 & 0.182649 & 0.002375 & 0.3280 \\
\hline \hline
\end{tabular}

Sumber : Output Eviews 8, Data diolah

Hasil dari uji signifikansi fixed effect dan random effect pada metode Hausman test adalah sebagai berikut. Pada table 1 diperoleh nilai chi square Statistik sebesar 1,6574 sedangkan nilai tabel chi-square dengan df sebesar 2 pada $\quad \alpha=1 \%$ sebesar 9,21. Berdasarkan nilai chi square maka menolak hipotesis satu (H1) sehingga berdasarkan uji Hausman model yang tepat untuk menganalisis perilaku kemampuan keuangan daerah di sepuluh kabupaten/kota tersebut adalah model Random effect.

\section{Hasil Uji Persamaan Regresi Linier Berganda}

Didalam persamaan regresi linier berganda, dikenal beberapa asumsi yang mendasari persamaan model yang menyangkut multikolineritas, heterokedastisitas dan autokorelasi. Dimana perlu dilakukan pengujian dimaksud dengan mengetahui apakah persamaan regresi yang ditentukan tersebut merupakan model yang dapat menghasilkan estimasi yang tidak bias. Adapun hasil pengujian tersebut dapat diuraikan sebagai berikut.

\section{Hasil Uji Multikolinieritas}

Uji Multikolinieritas dilakukan untuk mengetahui ada tidaknya hubungan yang signifikan diantara variabel bebas. Deteksi adanya multikolinieritas dilakukan dengan regresi suatu variabel bebas terhadap variabel bebas lain dalam model. Dari tabel hasil analisis uji multikolinieritas diatas terlihat bahwa $R$-square lebih kecil dari $R$-square statistik model utama yang berarti tidak terdapat masalah multikolineritas.

Tabel 2 Hasil Uji Multikolinieritas

\begin{tabular}{lrccr}
\hline \hline \multicolumn{1}{c}{ Variable } & Coefficient & Std. Error & t-Statistic & Prob. \\
\hline \hline C & 31288.71 & 1875.284 & 16.68478 & 0.0000 \\
PAD & 0.256889 & 0.075992 & 3.380498 & 0.0013 \\
\hline \hline R-squared & $\mathbf{0 . 1 6 4 5 9 9}$ & Mean dependent var & & 36599.13 \\
Adjusted R-squared & 0.150196 & S.D. dependent var & & 8605.898 \\
S.E. of regression & 7933.331 & Akaike info criterion & 20.82830 \\
Sum squared resid & $3.65 E+09$ & Schwarz criterion & 20.89811 \\
Log likelihood & -622.8490 & Hannan-Quinn criter. & 20.85561 \\
F-statistic & 11.42777 & Durbin-Watson stat & 1.015152 \\
Prob(F-statistic) & 0.001300 & & \\
\hline \hline
\end{tabular}

Sumber : Ouput eviews 8, data diolah 
Tabel 3 Hasil Estimasi Model Regresi Data Panel Random Effect (Model Utama)

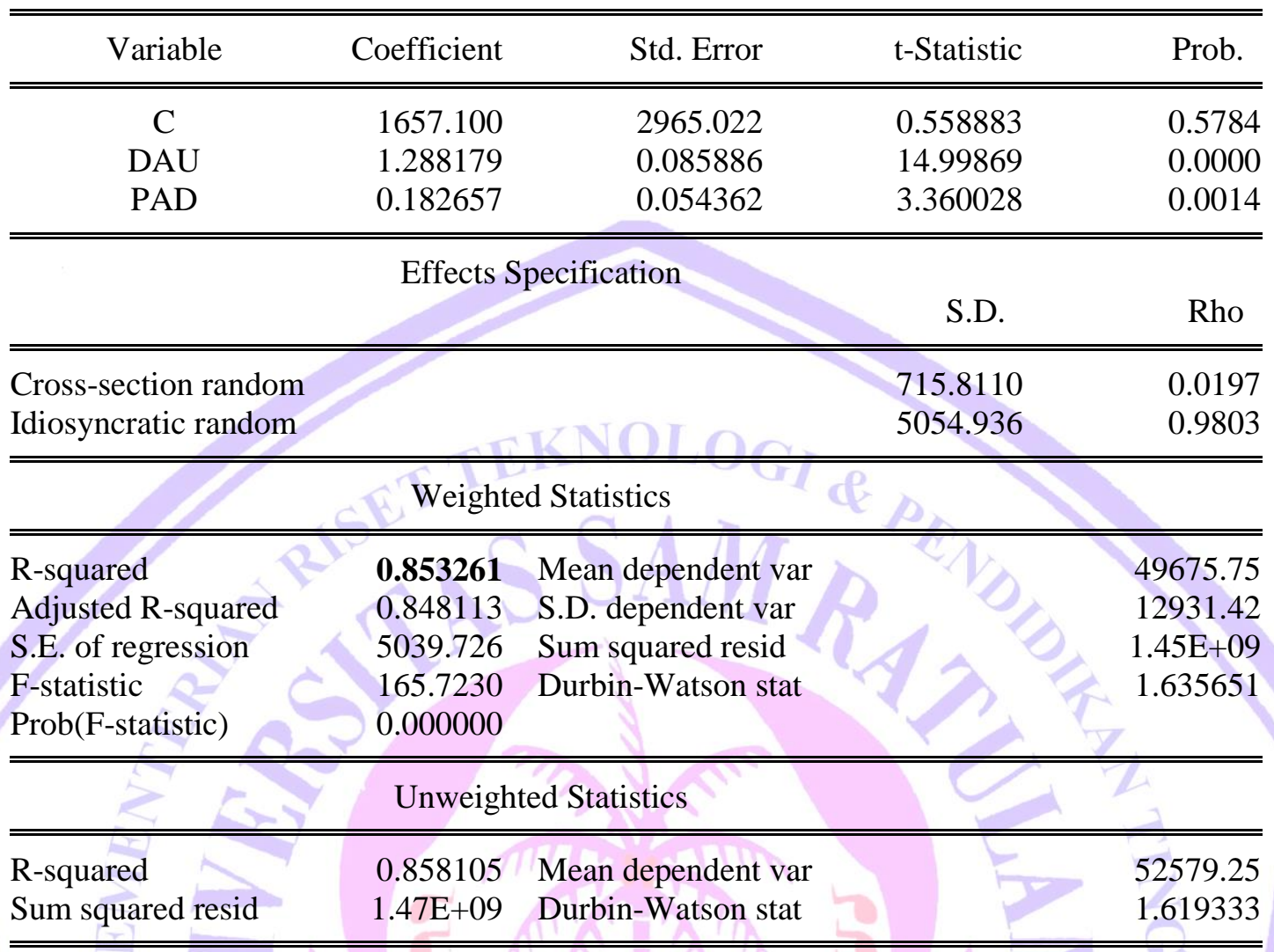

Sumber : Ouput eviews 8 , data diolah

\section{Hasil Uji Heterokedastisitas}

Pengujian white heterokedasticity test untuk mendeteksi ada tidaknya masalah heterokedastisitas dalam model. Berdasarkan table 4.10 hasil uji White memperoleh nilai obs chi-square statistik sebesar 2,4150 sedangkan nilai chi-square tabel pada $\quad \alpha=1 \%$ dengan $d f$ sebesar 2 adalah 9,21. Karena nilai obs chisquare statistik lebih kecil dari nilai chi-squares tabel maka hipotesis satu (H1) ditolak dan menerima hipotesis nol (H0) bahwa tidak ada masalah heterokedastisitas dalam model. Maka dengan tingkat keyakinan 99 persen dapat dikatakan bahwa tidak terdapat heterokedastisitas dalam model. 
Tabel 4 Hasil Uji white heterokedasticity tes

\begin{tabular}{lrllr}
\hline \hline F-statistic & 1.195261 & Prob. F(2,57) & & 0.3101 \\
Obs*R-squared & $\mathbf{2 . 4 1 5 0 5 4}$ & Prob. Chi-Square(2) & & 0.2989 \\
Scaled explained SS & 3.274677 & Prob. Chi-Square(2) & & 0.1945 \\
\hline \hline \multicolumn{1}{c}{ Variable } & Coefficient & Std. Error & t-Statistic & Prob. \\
\hline \hline \multicolumn{1}{c}{ C } & 27773192 & 13050276 & 2.128169 & 0.0377 \\
DAU^2 & 0.001643 & 0.008778 & 0.187229 & 0.8521 \\
\multicolumn{1}{c}{ PAD 2} & -0.009129 & 0.006005 & -1.520210 & 0.1340 \\
\hline \hline R-squared & 0.040251 & Mean dependent var & 24535188 \\
Adjusted R-squared & 0.006575 & S.D. dependent var & 42889529 \\
S.E. of regression & 42748286 & Akaike info criterion & 38.02826 \\
Sum squared resid & $1.04 E+17$ & Schwarz criterion & 38.13298 \\
Log likelihood & -1137.848 & Hannan-Quinn criter. & 38.06922 \\
F-statistic & 1.195261 & Durbin-Watson stat & 1.878318 \\
Prob(F-statistic) & 0.310095 & & \\
\hline \hline
\end{tabular}

Sumber : Ouput eviews 8, data diolah

\section{Hasil Uji Autokorelasi}

Uji autokorelasi dimaksudkan untuk mengetahui apakah terdapat korelasi residual satu observasi dengan observasi lainnya. Pengujian autokorelasi dilakukan salah satunya dengan breusch-godfrey serial correlation LM test. Hasil pengujian autokorelasi adalah sebagai berikut. Uji autokorelasi dimaksudkan untuk mengetahui apakah terdapat korelasi residual satu observasi dengan observasi lainnya. Pengujian autokorelasi dilakukan salah satunya dengan breusch-godfrey serial correlation LM test. Hasil pengujian autokorelasi adalah sebagai berikut.

Tabel 5 Hasil Uji breusch-godfrey serial correlation LM test

Breusch-Godfrey Serial Correlation LM Test:

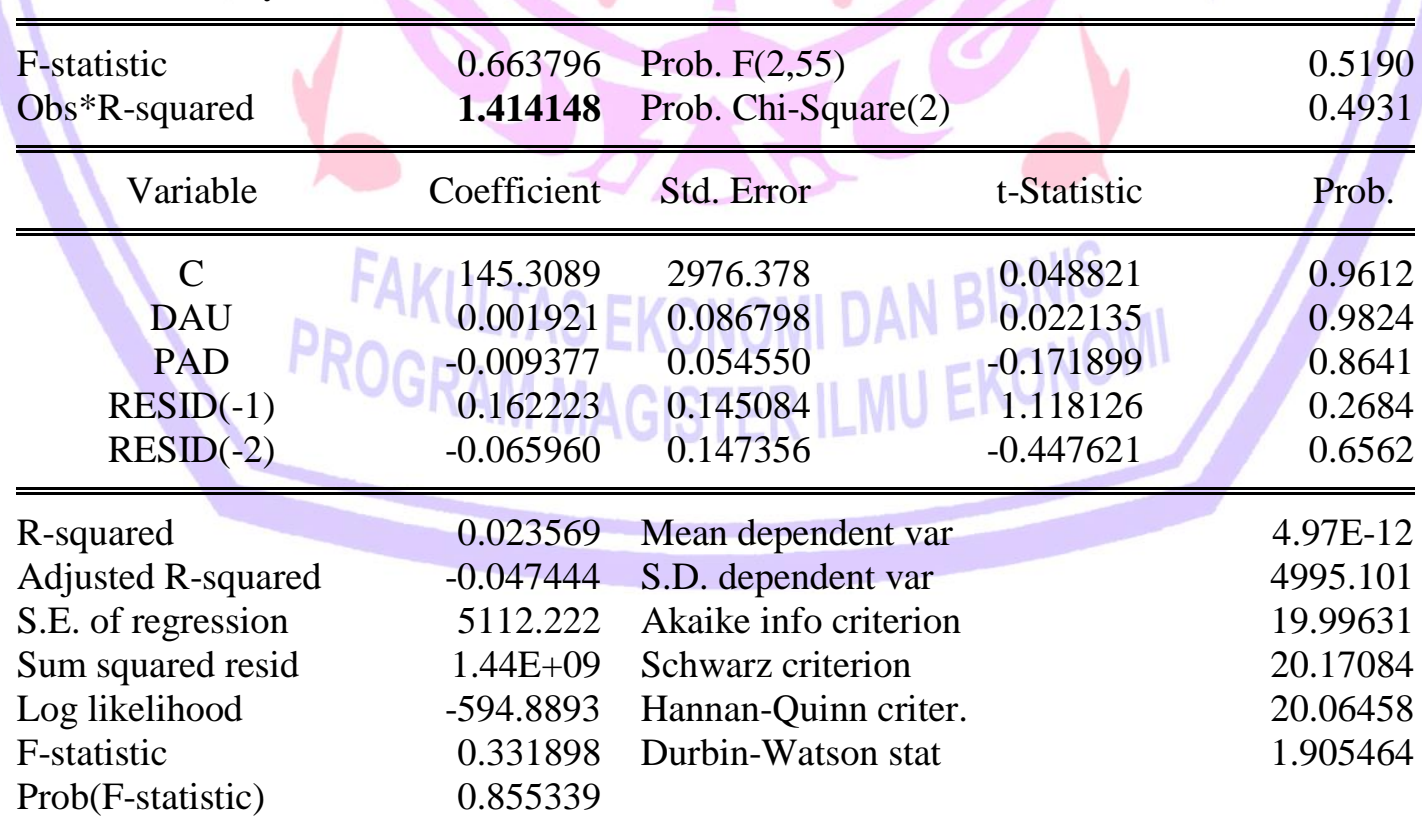

Sumber : Ouput eviews 8, data diolah 
Hasil Analisis Statistik Hasil Pengujian Secara Parsial (Uji t)

Tabel 6 Hasil Regresi Sederhana Variabel DAU terhadap belanja daerah

\begin{tabular}{lrrrr}
\hline \hline \multicolumn{1}{c}{ Variable } & Coefficient & Std. Error & t-Statistic & Prob. \\
\hline \hline C & 840.2685 & 3524.503 & 0.238408 & 0.8124 \\
DAU & 1.413667 & 0.092438 & $\mathbf{1 5 . 2 9 3 2 1}$ & 0.0000 \\
\hline \hline & & & & \\
\hline \hline R-squared & 0.803770 & Mean dependent var & & 35569.14 \\
Adjusted R-squared & 0.800386 & S.D. dependent var & & 11499.64 \\
S.E. of regression & 5137.823 & Sum squared resid & & $1.53 E+09$ \\
F-statistic & 237.5712 & Durbin-Watson stat & & 1.570918 \\
Prob(F-statistic) & 0.000000 & & \\
\hline \hline
\end{tabular}

Sumber : Ouput eviews 8, data diolah

Tabel 7 Hasil Regresi Sederhana Variabel PAD terhadap belanja daerah

\begin{tabular}{ccccc}
\hline \hline Variable & Coefficient & Std. Error & t-Statistic & Prob. \\
\hline \hline C & 43162.00 & 3363.022 & 12.83429 & 0.0000 \\
PAD & 0.455555 & 0.117971 & $\mathbf{3 . 8 6 1 5 7 7}$ & 0.0003 \\
\hline \hline R-squared & 0.205525 & Mean dependent var & 28929.72 \\
Adjusted R-squared & 0.191827 & S.D. dependent var & 10944.62 \\
S.E. of regression & 9839.041 & Sum squared resid & $5.61 \mathrm{E}+09$ \\
F-statistic & 15.00421 & Durbin-Watson stat & 1.489101 \\
Prob(F-statistic) & 0.000275 & & & \\
\hline \hline
\end{tabular}

Sumber : Output Eviews 8, Data diolah

\section{Hasil uji hipotesis variabel DAU}

Hasil regresi diperoleh nilai $\mathrm{t}$ statistik sebesar 15,2932 lebih besar dari nilai t tabel pada $\alpha=1 \%$ sebesar 2,704 dengan nilai koefisien DAU sebesar 1,4136 Artinya hubungan variabel DAU terhadap belanja daerah berpengaruh positif dan signifikan. Yang berarti ketika DAU naik satu miliar rupiah, maka jumlah belanja daerah akan naik sebesar 1,4136 miliar rupiah dengan asumsi variabel lainnya dianggap tetap. DAU dapat memiliki pengaruh yang signifikan dikarenakan DAU merupakan transfer pemerintah yang paling besar yang didapat oleh setiap daerah. Bahkan besarannya pun bisa melebihi nilai PAD yang dimiliki oleh setiap daerah walaupun tidak seluruh daerah yang DAU nya melebihi nilai PAD yang dimiliki oleh seluruh pemerintah daerah. Oleh karena itu maka wajar saja jika DAU memiliki pengaruh yang signifikan terhadap belanja daerah yang dilakukan oleh pemerintah daerah.

\section{Hasil uji hipotesis variabel PAD}

Hasil regresi diperoleh nilai t statistik sebesar 3,8615 lebih besar dari nilai t tabel pada $\alpha=1 \%$ sebesar 2,704 dengan nilai koefisien PAD sebesar 0,4555 Artinya hubungan variabel PAD terhadap belanja daerah berpengaruh positif dan signifikan. Yang berarti ketika PAD naik satu miliar rupiah, maka jumlah belanja daerah akan naik sebesar 0,4555 miliar rupiah dengan asumsi variabel lainnya dianggap tetap. PAD memiliki pengaruh yang signifikan terhadap belanja daerah karena PAD merupakan sumber penerimaan daerah dalam membiayai pelaksanaan pembangunan. 


\section{Hasil Pengujian Secara Simultan (Uji F)}

Tabel 8 Hasil Regresi Berganda Variabel PAD dan DAU Terhadap BD

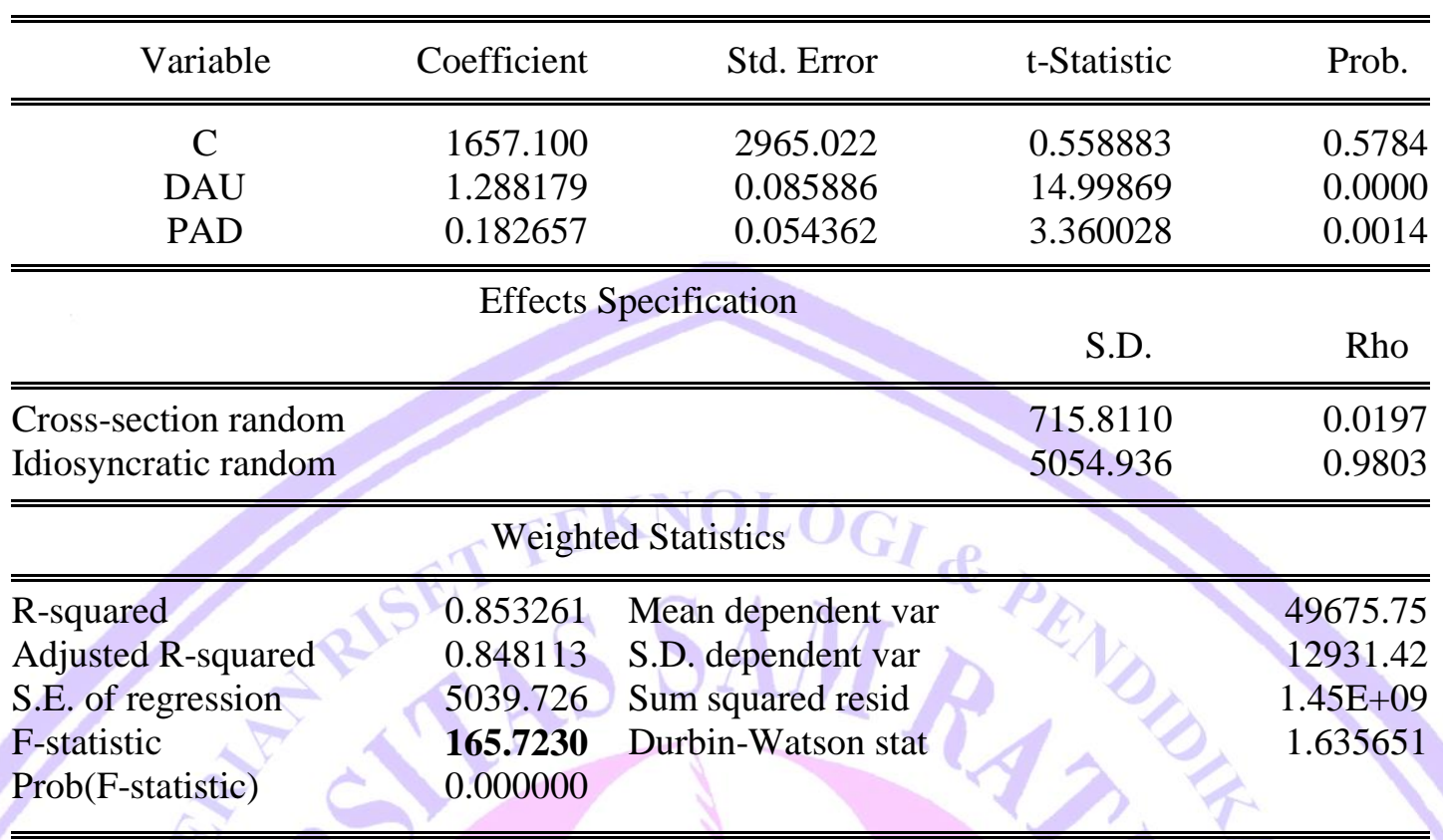

Sumber : Output Eviews 8, Data diolah

Hasil uji hipotesis variable DAU dan PAD Hasil regresi diperoleh nilai F statistik sebesar 165,7230 lebih besar dari nilai $F$ tabel pada $\alpha=1 \%$ sebesar 99,50 artinya bahwa, secara bersama-sama variable DAU dan PAD memiliki pengaruh terhadap belanja daerah pada periode 2007-2012

\section{Koefisien Determinasi $\left(\mathbf{R}^{2}\right)$}

Hasil analisis korelasi yang diperoleh dari output regresi mengkorelasi pengaruh yang diwakili oleh variabelvariabel bebas terhadap variabel terikat sehingga diperoleh nilai $R$ square $\left(R^{2}\right)$ adalah sebagai berikut

a. Pada model belanja daerah diperoleh nilai $\mathrm{R}^{2}=0,853261$. Angka ini menunjukan bahwa variasi nilai belanja daerah yang dapat dijelaskan oleh persamaan regresi yang diperoleh sebesar 85 persen sedangkan sisanya yaitu 15 persen dijelaskan oleh variabel lain diluar persamaan model.

b. Pada model belanja daerah tahun berjalan diperoleh nilai $\mathrm{R}^{2}=0,971151$. Angka ini menunjukan bahwa variasi nilai belanja daerah tahun berjalan yang dapat dijelaskan oleh persamaan regresi yang diperoleh sebesar 97 persen sedangkan sisanya yaitu 3 persen dijelaskan oleh variabel lain diluar persamaan model.

\section{Analisis Flypaper effect}

Koefisien DAU sebesar 1,2881 lebih besar dari koefisien PAD sebesar 0,1826 dimana memiliki arti bahwa terjadi flypaper effect pada Belanja Daerah Kabupaten/kota di Sulawesi Tengah atau dapat difungsikan jika $1,2881>0,1826$ berarti $\frac{1,2881}{0,1826}=7>1$ maka terjadi flypaper effect (Tresch, $\left.2002: 924\right)$. Kenaikan DAU disikapi pemerintah daerah Kabupaten/kota di Sulawesi Tengah. Hal ini sejalan dengan model Afrizawati (2012) bahwa penerimaan DAU bukan menjadi substitusi bagi upaya pengumpulan penerimaan dari daerah sendiri. Jika nilai variabel DAU meningkat sebesar satu miliar rupiah sedangkan nilai variabel lain tetap (cateris paribus) maka akan mengakibatkan naiknya belanja daerah sebesar 1,2881 miliar rupiah. 


\section{Hasil Pengujian DAU, PAD terhadap BD tahun berjalan}

Tabel 9 Hasil Uji Statistik Terhadap Peningkatan Jumlah Belanja Daerah

\begin{tabular}{|l|l|l|}
\hline Variabel & Tahun sebelumnya (t-1) & Tahun Berjalan $(\mathrm{t})$ \\
\hline DAU & 1,161040 & 1,643705 \\
\hline PAD & 0,157775 & 0,244860 \\
\hline
\end{tabular}

Sumber : Output Eviews 8, Data diolah

Dari hasil uji statistik yang ditunjukan pada tabel 9 memperlihatkan bahwa DAU dan PAD tidak dibandingkan dengan tahun yang sama pada belanja daerah melainkan menggunakan tahun sebelumnya. Maksud penggunaan data DAU, PAD dengan tahun berjalan adalah untuk melihat peningkatan dari pengaruh DAU, PAD tahun sebelumnya dengan belanja daerah tahun berjalan. dari hasil tersebut diperoleh nilai koefisien DAU tahun 2011 terhadap belanja daerah 2012 (1,6437) lebih besar dari DAU tahun 2012 terhadap belanja daerah tahun $2012(1,1610)$ demikian pula pada nilai koefisien PAD tahun 2011 terhadap BD $2012(0,2448)$ lebih besar dari PAD tahun 2012 terhadap belanja daerah tahun $2012(0,1577)$. Hasil Ini sejalan dengan penelitian Lambut dkk (2013), yang menunjukan bahwa kenaikan pendapatan melalui transfer yakni DAU dan PAD tahun 2011 mengakibatkan kenaikan pada belanja daerah tahun 2012 yang mengakibatkan terjadi flypaper effect.

\section{Pembahasan}

Adapun pembuktian dari hipotesis adalah dengan merujuk pada hasil perhitungan yang telah dilakukan sebagai berikut.

\section{Pengaruh DAU terhadap Belanja Daerah}

DAU adalah dana yang diberikan oleh pemerintah pusat kepada pemerintah daerah yang berasal dari APBN yang tujuan diberikannya dana ini adalah untuk pemerataan kemampuan antardaerah melalui penerapan formula yang mempertimbangkan kebutuhan daerah, kebutuhan akan belanja pegawai, kebutuhan fiskal, dan juga potensi daerah (UU No. 33 Tahun 2004). DAU ini juga diberikan oleh pemerintah pusat kepada pemerintah daerah untuk menjalankan sistem pemerintahan otonomi daerah agar dapat mencapai tujuan yang diinginkan yaitu kesejahteraan masyarakat di masing-masing daerah.

Dalam penelitian ini menemukan bahwa DAU di sepuluh Kabupaten/Kota di Sulawesi Tengah memiliki pengaruh signifikan dan lebih dominan dalam membiayai belanja daerah. Hal ini sejalan dengan hasil penelitian Maimunah (2006), Kurnia (2013), Lambut dkk (2013), dan Purbarini (2015). Sehingga dapat dikatakan pemerintah daerah dalam melakukan belanja tahun berjalan dipengaruhi oleh jumlah DAU yang diperoleh pada tahun yang sama. Menurut Oates (1996) menyatakan bahwa pengurangan jumlah transfer (cut in the federal grants) menyebutkan penurunan dalam pengeluaran daerah (dalam Sarjenedi, dkk, 2012). Hal tersebut juga tidak berbeda dengan penelitian Oktavia, (2014).

Hasil ini memperkuat teori penyusunan anggaran bersifat incrementalism, alokasi anggaran belanja daerah akan menyesuaikan dengan bertambah/berkurang jumlah anggaran pendapatan daerah. Hal ini menunjukan tingkat ketergantungan fiskal pemerintah daerah terhadap pemerintah pusat masih tinggi dan celah fiskal inilah yang akan ditutup dengan transfer dari pemerintah pusat dalam bentuk DAU.

Bagi pemerintah pusat, transfer diusahan menjadi pendorong agar pemerintah daerah secara intensif menggali sumber-sumber penerimaan sesuai kewenangannya. Namun kenyataannya alokasi transfer lebih banyak didasarkan pada aspek belanja tetapi kurang memperhatikan kemampuan pengumpulan pajak lokal. Akibatnya, dari tahun ke tahun pemerintah daerah selalu menuntut transfer yang lebih besar lagi dari pusat. Bukannya mengeksplorasi basis pajak lokal secara lebih optimal. Keadaan tersebut ditemui pada kasus pemerintah kabupaten/kota yang ada di Sulawesi Tengah. Transfer pemerintah pusat khususnya yang didominasi oleh DAU masih nampak berpengaruh dalam pembiayaan pembangunan. Hal ini terlihat dari besarnya porsi penerimaan DAU pada gambar 1.2 yang diperoleh daerah di kabupaten/kota pada tahun 20072012 daripada sumber penerimaan lainnya seperti transfer bersyarat, PAD atau pendapatan lain-lain. 


\section{Pengaruh PAD terhadap Belanja Daerah}

PAD dapat diartikan sebagai sumber keuangan daerah yang digali dari wilayah daerah yang bersangkutan yang mana terdiri dari pajak daerah, retribusi daerah, hasil pengelolaan kekayaan daerah yang dipisahkan dan lain-lain pendapatan yang sah (UU No. 28 Tahun 2009).

Dalam penelitian ini menemukan bahwa PAD di sepuluh Kabupaten/Kota Sulawesi Tengah memiliki pengaruh signifikan terhadap belanja daerah. Hasil ini sejalan dengan penelitian yang dilakukan oleh Maimunah (2006), Afrizawati (2012), Kurnia dan Ananda (2013), dan Oktavia (2014) yang mana dalam penelitiannya masing-masing menyatakan bahwa PAD memiliki pengaruh yang signifikan terhadap belanja daerah.

Hasil pengujian ini juga diperkuat oleh hubungan antara penerimaan PAD dengan belanja daerah yang mendukung the tax and spend hypothesis. Dimana dalam hipotesis ini perubahan pengeluaran pemerintah daerah ditentukan oleh besaran perubahan dalam penerimaan PAD. Dengan demikian dapat dikatakan kebijakan anggaran yang digunakan oleh pemerintah daerah Kabupaten/Kota di Provinsi Sulawesi Tengah dalam penyusunan APBD, kenaikan belanja daerah besar kecil perubahannya dari tahun ke tahun ditentukan oleh perubahan kenaikan dari penerimaan PAD. Kembali ke teori hubungan pendapatan daerah dengan beragam faktor-faktor yang dapat memberikan beberapa generalisasi penyebab utama perbedaan penerimaan pendapatan di masing-masing daerah, diantaranya faktor geografis, faktor historis, faktor politik, faktor administrasi, faktor sosial, dan faktor ekonomi. Dengan berdasarkan teori dan empiris serta dengan hasil penelitian yang dapat disimpulkan bahwa daerah-daerah yang pembangunan ekonominya sudah baik serta efektif dan efisien sehingga mampu membawa daerahnya memiliki daya saing yang tinggi seperti (Jawa dan Bali), yang berpotensi pada penerimaan pendapatan daerah (PAD) yang tinggi pula dibandingkan daerah yang masih kurang daya siang.

\section{Flypaper effect berpengaruh Pada Peningkatan Jumlah Belanja Daerah}

Besaran transfer tidak bersyarat dalam hal ini DAU secara signifikan mempengaruhi belanja daerah. Dalam jangka pendek kenaikan pada DAU akan meningkatkan kenaikan pengeluaran. Hasil ini membuktikan bahwa flypaper effect terjadi. Penelitian ini berbeda dengan hasil penelitian yang dilakukan oleh Pramuka (2010) di Jawa, Adiputra (2011), dan Darmayasa dan Sedanayasa (2012) di Bali. Ini dapat dikatakan bahwa pemerintah daerah dalam menetapkan kebijakan belanja daerah tahun berjalan lebih ditentukan oleh DAU yang telah diterima pada periode sebelumnya daripada PAD yang juga telah diperoleh pada periode sebelumnya. Kembali pada teori, fenomena flypaper effect diatas tampaknya lebih cocok dijelaskan dengan model birokratik. Pertama, masyarakat tidak bisa mempengaruhi tingkat bagi hasil pajak dan bukan pajak serta tarif pajak dan retribusi daerah. Kedua, birokrat memiliki keleluasaan dalam membelanjakan DAU, pajak daerah dan retribusi daerah yang diterimanya. Ketiga, sebelum dibelanjakan agenda pengeluaran disusun terlebih dahulu. Konsekwensinya, dengan kenaikan perolehan DAU dan PAD dengan tingkat yang tinggi pula. Fenomena ini sejalan dengan hasil studi Sagbas (2001) di turki. Hasil penelitian ini juga memperkuat teori "money sticks where it hits" flypaper effect yang terjadi diibaratkan bahwa dana transfer pusat hanya berpindah saja antara pemerintah pusat ke pemerintah daerah tanpa imbas dan pencapaian tujuan seharusnya dari dana tersebut dalam hal ini, seharusnya transfer pemerintah pusat dapat menstimulus perekonomian daerah melalui belanja daerah yang kemudian seharusnya menciptakan potensi fiskal dari perekonomian tersebut seperti misalnya melalui pajak, retribusi dll. Siklus inilah yang tidak terjadi pada Kabupaten/Kota di Sulawesi Tengah yang mengalami flypaper effect. Model birokratik juga menegaskan flypaper effect sebagai akibat dari perilaku birokratik yang leluasa untuk membelanjakan transfer daripada menaikkan pajak. Menurut hukum Wagner pengeluaran sektor publik akan tumbuh sejalan dengan perubahan struktur perekonomian dan kenaikan pendapatan masyarakat. Terutama disebabkan karena pemerintah harus mengatur hubungan yang timbul dalam masyarakat, hukum, pendidikan, rekreasi, kebudayaan dan sebagainya. Wagner mendasarkan pandangannya pada suatu teori yang disebut organic theory of state yaitu teori yang menganggap pemerintah sebagai individu yang bebas bertindak, terlepas dengan masyarakat lain. Berdasarkan hasil penelitian, maka dilihat dari kemampuan keuangan daerah Kabupaten/Kota di Sulawesi Tengah, ada dua jenis kondisi yang terkena flypaper effect. Pertama, adalah kondisi dimana daerah yang memang kesulitan dalam menciptakan dan menggali pendapatan daerah melalui potensi ekonominya. Hal ini disebabkan baik karena belanja daerah yang dikeluarkan tidak dapat 
menstimulasi investasi swasta dan pertumbuhan ekonomi atau kedua, karena memang minimnya sumber daya ekonominya.

Belanja daerah dipergunakan dalam rangka pelaksanaan urusan pemerintahan yang menjadi wewenang provinsi atau kabupaten/kota yang terdiri dari urusan wajib dan urusan pilihan yang ditetapkan dalam ketentuan perundang-undangan. Belanja penyelenggaraan urusan wajib diprioritaskan untuk melindungi masyarakat dalam upaya memenuhi kewajiban daerah yang diwujudkan dalam bentuk peningkatan pelayanan dasar pendidikan, kesehatan, fasilitas sosial dan fasilitas umum yang layak serta mengembangkan jaminan sosial. Pendapatan sendiri juga merupakan salah satu sumber pendapatan yang dapat digunakan dalam membiayai pelayanan publik. Flypaper effect membawa implikasi dimana salah satunya akan meningkatkan belanja pemerintah daerah lebih besar daripada penerimaan transfer itu sendiri serta kecenderungan untuk menanti bantuan dari pusat dibanding mengelola sumber daya daerah sendiri. Implikasi dari terjadinya flypaper effect pada belanja daerah kabupaten/kota seperti : Menyebabkan celah kepincangan fiskal akan tetap ada, menimbulkan ketidakmaksimalan dalam pemanfaatan sumber-sumber penghasil pertumbuhan $\mathrm{PAD}$, menyebabkan unsur ketergantungan daerah pada pemerintah pusat, adanya respon yang berlebihan dalam pemanfaatan dana transfer, dan mengakibatkan kurangnya kemampuan kemandirian keuangan daerah pada Kabupaten/kota yang bersangkuatan (Oktavia, 2013). Teori otonomi daerah dan desentralisasi fiskal dijelaskan bahwa secara garis besar fiskal dalam keuangan daerah dapat dibagi menjadi dua, yaitu manajemen penerimaan daerah dan manajemen pengeluaran daerah. Kedua komponen tersebut sangat menentukan kedudukan suatu pemerintahan daerah dalam rangka melaksanakan otonomi daerah (Sudirman, 2011). Implementasi desentralisasi fiskal dan otonomi daerah yang didasarkan pada Undang-undang Nomor 23 Tahun 2014 dan Undang-undang Nomor 25 Tahun 1999 tentang Perimbangan Keuangan Pusat dan Daerah, memberikan kewenangan yang luas dan nyata kepada pemerintah daerah untuk mengelola dan mengatur sumber daya sesuai dengan kepentingan masyarakat daerahnya. Pemerintah daerah berwenang untuk menetapkan prioritas pembangunan sesuai dengan potensi dan sumber daya yang dimiliki. Dengan adanya perubahan sistem pemerintahan dari sentralistik ke desentralistik yang dimulai pada tahun anggaran 2001 ini membawa konsekuensi perlunya diadakan perubahan pendekatan pada manajemen keuangan daerah terutama pada sisi pengelolaan fiskal. Kebijakan perimbangan keuangan antara pemerintah pusat dan daerah juga perlu disesuaikan dengan semangat pelaksanaan otonomi daerah yakni dengan menerapkan kebijakan desentralisasi fiskal. Sementara itu, dalam pelaksanaan desentralisasi fiskal, kebijakan pengalokasian anggaran belanja daerah dalam bentuk dana perimbangan tetap konsisten dengan kebijakan fiskal nasional. Kebijakan dimaksud lebih diarahkan untuk memperkecil ketimpangan keuangan antara pemerintah pusat dan daerah dengan tetap menjaga netralitas fiskal, memperkecil ketimpangan, meningkatkan akuntabilitas, serta efisiensi dan efektivitas kinerja pemerintah daerah Kabupaten/Kota di Provinsi Sulawesi Tengah.

\section{KESIMPULAN DAN SARAN}

Berdasarkan pada teori-teori dan pembuktian baik secara empiris maupun ekonomi mengenai pengaruh DAU dan PAD terhadap belanja pemerintah daerah dan flypaper effect yang menyebabkan peningkatan jumlah belanja daerah Kabupaten/Kota di Provinsi Sulawesi Tengah pada tahun 2007 sampai dengan 2012, maka dapat ditarik kesimpulan dan saran sebagai berikut.

\section{Kesimpulan}

1. Pengaruh DAU dan PAD terhadap belanja daerah selang periode tahun 2007-2013 memberikan informasi bagaimana pengaruh variabel DAU dan PAD terhadap belanja daerah. Hal ini ditunjukan analisis sebagai berikut.

a. Terdapat pengaruh yang positif dan signifikan variabel DAU terhadap belanja daerah. Hal ini berarti peningkatan DAU di sepuluh Kabupaten/Kota di Provinsi Sulawesi Tengah juga diikuti dengan peningkatan pertumbuhan belanja daerah.

b. Terdapat pengaruh yang positif dan signifikan variabel PAD terhadap belanja daerah. Hal ini berarti PAD di sepuluh Kabupaten/Kota di Provinsi Sulawesi Tengah adalah faktor yang cukup dominan dalam 
menentukan penyusunan, perencanaan dan pelaksanaan pembangunan daerah, yang sebagaimana terwujud pada perkembangan anggaran daerah (APBD).

2. Terjadi flypaper effect pada sepuluh Kabupaten/Kota di provinsi Sulawesi Tengah. Dilihat dari besarnya koefisien DAU dibandingkan koefisien PAD terhadap belanja daerah.

3. Flypaper effect menyebabkan kenaikan pada belanja daerah tahun berjalan.

\section{Saran}

1. Mengingat PAD sangat berpengaruh terhadap perkembangan belanja daerah di Provinsi Sulawesi Tengah, maka peningkatan efektivitas dan efisiensi dalam perolehan sumber-sumber PAD harus lebih diintensifkan.

2. Memahami bahwa DAU tersebut hanyalah sebagai pemicu kemandirian suatu daerah sebagai langkah awal keberhasilan otonomi. Sehingga dengan alokasi dana tersebut, dapat bergerak aktif dalam menggali sumber-sumber PAD yang berpotensi dapat menaikkan persentase penerimaan PAD dan menurunkan alokasi.

3. Penelitian ini masih jauh sempurna, untuk itu disaran untuk penelitian selanjutnya sebaiknya periode waktu/tahun ditambah sehingga menghasilkan informasi yang lebih mendukung. Disamping itu variabel belanja daerah dibuat menjadi beberapa variabel sesuai dengan rincian atau item belanja daerah sehingga nantinya diharapkan kesimpulan yang diperoleh lebih sempurna. dapat bergerak aktif dalam menggali sumber-sumber PAD yang berpotensi dapat menaikkan persentase penerimaan PAD dan menurunkan alokasi.

\section{DAFTAR PUSTAKA}

Adiputra, I Made Pradana. 2014. "Flypaper Effect Pada Dana Alokasi Umum (DAU) dan Pendapatan Asli Daerah (PAD) terhadap Belanja Daerah di Kabupaten Karangasem". Jurnal Ilmiah Akuntansi dan Humanika JINAH, Vol. 3 No. 2 Singaraja, Bali.

Adisasmita, Rahardjo. 2011. Pengelolaan Pendapatan dan Anggaran Daerah. Graha Ilmu : Yokyakarta.

Afrizawati. 2012. "Analisis Flypaper Effect Pada Belanja Daerah Kabupaten/Kota Di Sumatera

Selatan". Jurnal Ekonomi dan Informasi Akuntansi Vol 2 No.1.

Anonim. 2013. Pedoman Penyusunan APBD Anggaran Pendapatan dan Belanja Daerah 2013-2014.

Fokusindo Mandiri : Bandung

Anonim. 2002. "Dampak desentralisasi fiscal di Indonesia terhadap pertumbuhan ekonomi". LPEM - UI

Fakultas Ekonomi. Universitas Indonesia. Jakarta

Al Khoiri, Rifki Hasan. 2015. “ Flypaper Effect dan Belanja Daerah di Provinsi Jawa Barat “. Signifikan vol. 4 no. 2, oktober

Becker, E. 1996. "The Illusion of Fiscal Illusion : Unticking the flypaper effect”. Publick Choice. 86 (1/2), februari : 85 - 102

Blackley, P. 1986. "Causality between revenues and expenditures of the size of Federal budget". Public Finance quarterly 14: 139-156.

Boediono. 2011. Pengantar Ilmu Ekonomi No.1 Ekonomi Mikro. Fakultas Ekonomika \& Bisnis. Universitas Gaja Mada. Yokyakarta.

Cerdenas, Oskar J, dan Ama Reandra Sharma. 2011. "Mexican municipalities and the flypaper effect". Mexico : Publick Financial Publications.

Darmayasa, I Nyoman. Sedanayasa, I Made. 2012. "Flypaper Effect Dana Alokasi Umum dan Pendapatan Asli Daerah Terhadap Belanja Modal (Studi Kasus Pada Kabupaten dan Kota di Bali) “. Jurnal Bisnis dan Kewirausahaan. Vol.8 no.3, November.

Darwanto, dan Yulia Yustika Sari. 2007. "Pengaruh Pertumbuhan Ekonomi, Pendapatan Asli Daerah, dan Dana Alokasi Umum terhadap Pengalokasian Anggaran Belanja Modal”. Makalah disampaikan dalam Simposium Nasional Akuntansi X. Makasar. 26 - 28 Juli 2007.

Deller, C. Steven and Craig, S. Maher. 2005. "Categorical Municipal Expenditures with a Focus on the Flypaper Effect". Public Budgeting \& Finance, Vol. 5, no.3, page 73-90. 
Deller, C Steven, et al. 2002. "Winconsin local government, state shared revenues and the illusive flypaper effect". University of Winconsin-Madison, Working Paper.

Emelia. 2006. Mengukur Tingkat Kemandirian Keuangan Daerah Dalam Mendorong Pelaksanaan Otonomi Daerah Periode 2000-2004 di Kabupaten Lampung Timur. Skripsi Tidak Dipublikasikan. Fakultas Ekonomi, Universitas Islam Indonesia Yokyakarta.

Jdohanputro, Bramantyo. 2008. Prinsip-prinsip Ekonomi Makro. Jakarta : PPM.

Sarwono, Jonathan. Hendra N.S. 2014. Eviews : Cara Operasi dan Prosedur Analisis. ANDI. Yokyakarta.

Fillimon, R et al. 1982. "Asymetric Information and Agenda Control". Journal of Publick Economics. 17 (2), februari : $51-70$.

Gorodnichenko, Y. 2001. "Efects of Intergovernmental Aid on Fiscal Behavior of Local Governments: The Case of Ukraine". Master Thesis, University of

Kiev,http://www.eerc.kiev.ua/research/matheses/2001/pdf/gorodnichenko. pdf.

Gramlich, E.M. 1977. "Intergovernmental Grants: A Review of the Empirical” Literature, dalam W.E. Oates, (Ed.), The Politic Economy of Fiscal Federalism, Lexington Books, Lexington MA: 219-40.

Halim, Abdul. Iqbal, Muhammad. 2012. Pengelolaan Keuangan Daerah. STIM YKPN, Yokyakarta.

Handayani, Atiah. 2009. Analisis Pengaruh Transfer Pemerintah Pusat Terhadap Pengeluaran Daerah dan Upaya Pajak (Tax Effort) Daerah (Studi Kasus : Kabupaten/Kota Di Jawa Tengah). Skripsi Tidak

Dipublikasikan, Ilmu Ekonomi dan Studi Pembangunan. Universitas Diponegoro Semarang.

Hines, J.R. \& Richard H. Thaler. 1995. Anomalies - the flypaper effect. Journal of economic perspektives 9 (4) : $217-226$

Kalonta, Benny. 2013. Analisis Keuangan Daerah Dan Hubungan Kausalitas Pendapatan Asli Daerah Dengan Belanja Pemerintah Di Provinsi Sulawesi Utara. Tesis Ilmu Ekonomi, Universitas Sam Ratulangi Manado.

Kang, Younguck \& Setyawan, Dhani. 2012. “Intergovernmental Transfer And The Flypaper Effect Evidence From Municipalities/Regencies In Indonesia”. Working Papers Series. KDI School of Public Policy and Management, Korea.

Kuncoro, Haryo. 2007. "Fenomena Flypaper Effect pada Kinerja Keuangan Pemerintah Daerah Kota dan Kabupaten di Indonesia". Makalah disampaikan dalam Simposium Nasional Akuntansi X. Makasar. 26-28 Juli 2007.

Kurnia, Eka Daddy. 2013. “Analisis Flypaper effect Berdasarkan Pemetaan Indeks Kemampuan Keuangan dan Pertumbuhan Ekonomi (Studi kasus pada kabupaten/kota di Jawa Timur)". Jurusan Ilmu Ekonomi Fakultas Ekonomi dan Bisnis Universitas Brawijaya Malang.

Kusumadewi, Diah Ayu, dan A. Rahman. 2007. "Flypaper Effect pada Dana Alokasi Umum (DAU) dan Pendapatan Asli Daerah (PAD) terhadap Belanja Daerah pada Kabupaten/Kota di Indonesia “. JAAI, Juni 2007, Vol. 11, No.1,pp. 67-80.

Maimunah, Mutiara. 2006. “Flypaper Effect pada Dana Alokasi UMUM (DAU) dan Pendapatan Asli Daerah (PAD) terhadap Belanja Daerah pada Kabupaten/Kota di Pulau Sumatera “. Makalah disampaikan dalam Simposium Nasional Akuntansi. Padang. 23 - 26 Agustus 2006.

Mardiasmo. 2004. Otonomi dan Manajemen Keuangan Daerah. Universitas Gadjah Mada, Yokyakarta : ANDI.

Marthen Anton Phentury. 2011. Flypaper Effects Anomaly of West Papua Capital Publik Expenditure. 2011. STIA Asy - Syafi'iyah Fakfak Papua Barat.

Mithami. D.M.dkk. 1999. "Causality Between Government Expenditure and Revenue In Malaysia". ASEAN Economic Bulletin Vol 16 No 1.

Mulyadi. 2006. Ekonomi Sumber Daya Manusia : dalam perspektif pembangunan. Jakarta.

Musgrave R.A and Musgrave P.B. 1993. Keuangan Negara Dalam Teori dan Praktek, Edisi kelima, Erlangga Jakarta.

Melo, L. 2002. "The flypaper effect under defferent institutional contexts : the Colombian case ". Publick cioce, III (3-4), $317-345$.

Naganathan, M. dan K.J. Sivagnanam, (1999), "Federal Transfers and Tax Efforts of States in India", Indian Economic Journal, 47(4), April: 101-10. 
Ndadari, Laras Wulan, dan Priyo Hari Adi. 2008. "Perilaku Asimetris Pemerintah Daerah terhadap Transfer Pemerintah Pusat". Makalah disampaikan dalam The and National Conference UKWMS. Surabaya. 6 September 2008.

Oates, Wallace. 1999. “An Easy of Fiscal Federalism” Journal of Economics Literature 37:1120-1149.

Oktavia, Deni. 2014. " Flypaper Effect : fenomena serial waktu dan lintas kabupaten/kota di jawa timur 2003-2013 “. Program pascasarjana fakultas ekonomi. Universitas jember.

Penthury, M.A. 2011. " Flypaper Effects Anomaly Of West Papua Capital Public Expenditure “. Economic Journal Of Emerging Markets, 3(3), pp: 289-297.

Purbarini, Endah. Gregorius, N. Masdjojo. 2015. "Flypaper Effect on Operating Expenditure and Capital Expenditure of the City Government in Indonesia". Jurnal Ekonomi Pembangunan, 16 (1), Juni, 75 84.

Purnomo, Hermawan Bayu. 2011. "Flypaper Effect Pada Pengeluaran Transfer Tidak Bersyarat dan Pendapatan Asli Daerah Terhadap Pertumbuhan Ekonomi Daerah Kabupaten/kota di Kalimantan Tahun 2007-2010". Fakultas Ekonomi dan Bisnis Universitas Padjajaran Bandung.

Pramuka, Bambang Agus. 2010. " Flypaper Effect Pada Pengeluaran Pemerintah Daerah Di Jawa “. Jurnal Ekonomi Pembangunan.

Republik Indonesia. (1999). Undang- undang Republik Indonesia Nomor 25 Tahun 1999 tentang Perimbangan Keuangan antara Pemerintah Pusat dan Daerah.

Republik Indonesia. (2010). Undang- undang Republik Indonesia Nomor 71 Tahun 2010 tentang Standar Akuntansi Pemerintah

Republik Indonesia. (2014). Undang- undang Republik Indonesia Nomor 23 Tahun 2014 tentang Pemerintahan Daerah

Republik Indonesia. (1999). Undang- undang Republik Indonesia Nomor 22 Tahun 1999 tentang Pemerintahan Daerah

Rokhaniyah, Siti \& Nugroho, Muh.Rudi. 2011. Analisis Flypaper Effect Pada Belanja Pemerintah Kota dan Kabupaten Di Indonesia Tahun 2006-2008. Fokus Ekonomi (FE). Agustus 2011. Hal. 100-113, Vol. 10 No 2 ISSN : 1412-3851

Sarjenedi et al. 2012. "Flypapet Effect Pada Dana Alokasi Umum dan Pendapatan Asli Daerah Terhadap Belanja Daerah Kabupaten/kota Hasil Pemekaran di Pulau Sumatra “. Jurusan Akuntansi Fakultas Ekonomi Bung Hatta.

Schwille, D.P. 1989. " The Impact of Intergovermental Grants on the Aggregate Public Sector “. Quarum books greenwood press, New York.

Shah, A., (1994), “ The Reform of Intergovernmental Fiscal Relations in Developing and Emerging Market Economies ", Policy and Paper Series, No. 23, The World Bank, Washington, DC.

Subandi. 2011. Ekonomi Pembangunan. Bandung: Alfabeta

Sudirman, I Wayan. 2011. Kebijakan Fiskal dan Moneter : Teori dan Empirikal. Prenada Media : Rawangmangun, Jakarta.

Sukirno, Sadono. 2010. Mikro Ekonomi : Teori Pengantar. Jakarta.

Shinta, Dian Ayu. 2009. " Perilaku Asimetris Pemerintah Daerah terhadap Transfer dari Peme- rintah Pusat pada Kabupaten/Kota di Jawa Tengah “. Skripsi. Sarjana Ekonomi Akuntansi Universitas Jenderal Soedirman. Purwokerto. (Tidak dipublikasikan).

Tresch, Richard. 2002. "Finance Public Anormative Theory ”.Department of Economic, Boston College Chestnut Hill, Massachusetts.

Turnbull, G.K. 1992. "Fiscal Illusion, Uncertainty and the flypaper effect “. Journal Public of Economics, 48 (2), Juli : $2007-203$

Yustika, Ahmad Erani. 2008. Desentralisasi Ekonomi Di Indonesia : Kajian Teoritis dan Realitas Empiris. Penerbit Bayu Media, Malang.

Widardjono, Agus. 2013. Ekonometrika Pengantar dan Aplikasinya Disertai Panduan Eviews. UPP STIM YKPN. Yokyakarta.

Widodo, Pambudi Tri. 2007. "Flypaper Effect pada Dana Alokasi UMUM (DAU) dan Pendapatan Asli Daerah (PAD) terhadap Belanja Daerah pada Kabupaten/Kota di Bali (Studi pada Kabupaten/Kota di Bali) “. http://rac.uii.ac.id/server/document/private/2008072511265203312374.pdf. diakses 3 september 2009 